\title{
RESILIENSI ORANG DENGAN HIV/AIDS (ODHA)
}

\author{
Eva Ardana \\ Yulia Sholichatun \\ Fakultas Psikologi \\ Universitas Islam Negeri (UIN)Maulana Malik Ibrahim Malang \\ Jl. Gajayana 50 Malang Telp. 0341-558916
}

\begin{abstract}
Abstrak - Penelitian ini bertujuan untuk mengetahui aspek-aspek resiliensi pada orang dengan HIV/AIDS (ODHA), faktor-faktor pembentuk resiliensi pada orang dengan HIV/AIDS (ODHA), faktor protektif yang mempengaruhi orang denganHIV/AIDS (ODHA) dan tahapan resiliensi orang dengan HIV/AIDS (ODHA). Penelitian ini menggunakan metode penelitian kualitatif studi kasus. Subyek dalam penelitian ini menggunakan dua orang dengan kriteria yang telah ditentukan.Lokasi penelitian ini dilakukan disebuah LSM, disebuah Puskesmas dan dikediaman kedua subyek.Pengumpulan data yang digunakan dalam penelitian ini adalah wawancara dan observasi.Hasil dari penelitian menunjukkan bahwa kedua subyek telah mencapai resiliensi. Terdapat beberapa aspek-aspek yang mempengaruhi terbentuknya resiliensi yaitu I am, I have dan I can. Selain hal tersebut, terdapat faktor-faktor yang mempengaruhi resiliensi yaitu regulasi emosi, kontrol impulsif, optimis, empati, self efikasi, causal analisis dan reaching out.Sedangkan faktor protektif yang mempengaruhi terbentuknya resiliensi yaitu dukungan dari keluarga dan teman sesama ODHA, anak sebagai penyemangat diri, tingkat religiusitas, dan menerapkan pola hidup sehat. Kedua subyek juga melewati semua level resiliensi yaitu succumbing, survival, recovery dan thryving.
\end{abstract}

Kata Kunci : Resiliensi, Orang, HIV/AIDS

PSIKOISLAMIKA. Jurnal Psikologi Islam (JPI) copyright @ 2014 Laboratorium Penelitian, Kajian Psikologi Islam dan Penerbitan. Volume 11. Nomor 1, Tahun 2014

\section{PENDAHULUAN}

Seks bebas dan narkoba sudah menjalar di Indonesia terutama di lingkungan para remaja. Perilaku beresiko seperti hubungan seks tanpa pengaman (kondom), penggunaan narkoba suntik yang menggunakan jarum suntik secara bergantian dan tidak steril, penggunaan jarum tindik atau jarum tato yang tidak steril dapat mengakibatkan seseorang terinfeksi Human Immunodeficiency Virus (HIV). HIV menyerang sel-sel darah putih sehingga daya tahan tubuh menjadi menurun (Hawari, 2006, hal. 89). Untuk memperlambat penyebaran penyakit dalam tubuh, ODHA harus meminum obat antirethoviral atau yang biasa disebut dengan ARV. Seseorang yang terinfeksi HIV akan mengalami penyakitpenyakit opportunities seperti TBC, diare, kanker, penyakit kulit dan penyakit lain yang membahayakan kehidupanya (Hawari, 2006, hal. 89).
Menurut Joerban (dalam Astuti, 2008), hampir 99\% penderita HIV/AIDS mengalami stres berat, Djoerban juga menemukan sejumlah pasien HIV/AIDS yang mengalami depresi berat, dimana pada saat mengetahui dirinya mengidap penyakit AIDS, banyak ODHA yang tidak bisa menerima kenyataan bahwa dirinya tertular HIV/AIDS, sehingga menimbulkan depresi dan kecenderungan bunuh diri pada diri ODHA itu sendiri (Astuti, 2008, hal. 2).

Richard (dalam Saputa, 2009) menjelaskan bahwa respon stres psikologi biasanya muncul saat diagnosa diberikan kepada pasien, pasien bisa merasa tidak yakin, terkejut dan melakukan penyangkalan serta diikuti dengan kemarahan dan kekacauan akut dengan gejala-gejala kecemasan yang tinggi dan depresi (Saputra, 2009, hal. 5).Untuk mewujudkan kehidupan yang lebih baik, maka ODHA harus mampu mengatasi tekanan psikologis maupun tekanan fisik 
akibat dari penyakitnya tersebut. Untuk itu maka ODHA membutuhkan sikap yang resilien.

Berdasarkan pemaparan diatas, peneliti ingin mengetahui bagaimana resiliensi orang dengan HIV/AIDS (ODHA). Beberapa sub yang ingin dijawab dalam penelitian ini adalah mengenai aspek-aspek pembentuk resiliensi pada Orang dengan HIV/AIDS (ODHA), faktor-faktor yang dapat mempengaruhi resiliensi pada Orang dengan HIV/AIDS (ODHA), faktor protektif dapat mempengaruhi resiliensi pada Orang dengan HIV/AIDS (ODHA), tahap-tahap resiliensi yang telah dilalui oleh Orang dengan HIV/ AIDS (ODHA).

\section{KAJIAN PUSTAKA}

Luthar dkk mengungkapkan bahwa "resilience refers to a dynamic prosess encommpasing positive adaption within the context of cignificant adversity". Luthar dkk, menganggap bahwa resiliensi sebagai sebuah proses dinamis yang dapat menghasilkan adaptasi positif dari kemalangan yang pernah dialaminya (McCubbin, 2001, hal. 2). Resiliensi adalah kemampuan dari kapasitas individu untuk "bangkit kembali" dari pengalaman negatif atau merupakan hasil dari pembelajaran dan pengalaman (Building resilience in rural communities, 2008, hal. 3).

Menurut Reivich dan Shatte, resiliensi merupakan kemampuan individu untuk mengatasi dan meningkatkan ketahanan diri terhadap situasi yang menekan seperti kehilangan pekerjaan, kegagalan dalam berhubungan sosial, dan bahkan trauma yang terjadi dalam hidupnya (Shatte, 2002, hal. 1).Grotberg (1994) menyebutkan tiga sumber dari resiliensi (three sources of resilience) untuk mengatasi konflik yang disebabkan dari keadaan yang tidak menyenangkan dan untuk mengembangkan resiliensi remaja. Sumber-sumber tersebut yaitu (Desmita, 2005, hal. 229). I Am: Sumber resiliensi pada faktor I am berasal dari dalam diri individu. Sumber-sumber tersebut meliputi perasaan, sikap dan keyakinan yang dimiliki oleh individu. I Have: Faktor I have merupakan salah satu sumber pembentuk resiliensi yang berasal dari luar diri individu. Dalam hal ini besarnya dukungan sosial yang diberikan oleh orang lain sangat membantu dalam terbentuknya resiliensi (Desmita, 2005, hal. 229). I Can: Sumber I can merupakan sumber pembentuk resiliensi yang berkaitan dengan keterampilan yang dimiliki oleh individu dalam menjalin hubungan sosial dan interpersonal (Desmita, 2005, hal. 230).

Reivich dan Shatte (2002) menyebutkan tuju faktor yang dapat membentuk resiliensi, yaitu
(Reivich, 2002, hal. 33) Emotion regulation: Regulasi emosi merupakan kemampuan yang dimiliki oleh setiap individu untuk tetap tenang walaupun berada dibawah kondisi yang menekan hidupnya (Reivich, 2002, hal. 36). Impulsive control: Kemampuan individu untuk mengendalikan dorongan ataupun keinginan yang muncul dalam dirinya (Reivich, 2002, hal. 39). Optimism: Individu yang optimis mempunyai harapan dan percaya bahwa kehidupan mereka dapat berubah menjadi lebih baik dan yakin bahwa individu tersebut mampu untuk mengatasi keadaan yang tidak menyenangkan yang akan terjadi dalam kehidupan (Reivich, 2002, hal. 40-41). Causal analysis: yaitu sebuah kemampuan yang dimiliki oleh individu untuk mengidentifikasi secara lebih akurat tentang penyebab dari permasalahan yang sedang mereka hadapi dalam kehidupannya (Reivich, 2002, hal. 41). Empaty: kemampuan yang dimiliki individu untuk mengetahui tanda/isyarat psikologis atau emosional yang diperlihatkan oleh orang lain (Reivich, 2002, hal. 44). Self eficacy: adalah sebuah keberhasilan dalam memecahkan sebuah masalah yang sedang dihadapi. Self eficacy terdapat sebuah keyakinan individu bahwa dirinya dapat menyelesaikan masalah yang sedang dihadapinya untuk mencapai sebuah kesuksesan (Reivich, 2002, hal. 45). Reaching out: Ketidakmampuan individu untuk melakukan reaching out dikarenakan sejak kecil individuindividu tersebut diajarkan menghindari kegagalan dan menghindari kejadian yang memalukan dalam hidupnya (Reivich, 2002, hal. 46).

Terdapat dua faktor yang selalu dikaitkan dalam kajian resiliensi, yaitu faktor protektif -(protective factor) dan fakto resiko (risk factor). Dyer \& McGuinness (dalam Earvolino) mendefinisikan faktor protektif atau yang biasa disebut dengan faktor pelindung sebagai sifat (attributes) atau situasi tertentu dimana situasi tersebut diperlukan dalam proses terbentuknya resiliensi (Earvolino, 2007, hal. 75-76).

Faktor resiko dalam resiliensi merupakan kemungkinan terdapatnya keadaan yang tidak menyenangkan yang dirasakan oleh individu seperti anggota dari kelompok beresiko tinggi, yaitu anakanak yang tumbuh pada keluarga yang memiliki status ekonomi rendah, besar pada lingkungan yang penuh kekerasan, lahir dalam keadaan cacat, cidera atau mempunyai penyakit, pengalaman stres dan trauma. Faktor resiko dapat berasal dari faktor biologis, faktor psikologis, lingkungan dan sosial-ekonomi yang mempengaruhi kemungkinan terdapatnya kerentanan terhadap stres (Schoon, 
2006, hal. 9).Tahapan-tahapan yang dilalui oleh setiap individu yang mengalami ancaman atau kondisi yang menekan disebut dengan level resiliensi. O'Leary dan Ickoviks (dalam Coulson) membagi resiliensi menjadi empat level yaitu (Coulson, 2006, hal. 5). Succumbing (mengalah); Kondisi yang dialami oleh individu pada level ini yaitu kondisi menurun, disini individu mengalah atau menyerah setelah menghadapi suatu ancaman atau kondisi yang menekan dalam hidupnya. Outcome dari kondisi ini adalah individu berpotensi mengalami depresi, pemakaian narkoba sebagai pelarian, dan pada tataran yang lebih ektrim dapat mengakibatkan bunuh diri (Coulson, 2006, hal. 5-6). Survival (bertahan); Survival merupakan kondisi yang menunjukkan ketidakmampuan individu untuk meraih kembali atau mengembalikan fungsi psikologis dan emosi yang mereka miliki setelah menghadapi kesulitan dalam hidupnya (Coulson, hal. 6). Recovery (pemulihan); Pada level ini individu telah mampu pulih kembali (bounce back) pada fungsi psikologis dan emosinya, individu telah dapat beradaptasi dengan kondisi yang menekan dalam hidupnya, meskipun masih terdapat beberapa efek negatif dari perasaan yang tersisa (Coulson, 2006, hal 6). Thriving (berkembang dengan pesat); Level ini merupakan keadaan dimana individu tidak hanya mampu untuk pulih kembali pada level fungsi sebelumnya, akan tetapi individu telah menunjukkan bahwa dirinya mampu untuk melampaui pada beberapa respek setelah mengalami kondisi yang menekan (Coulson, 2006, hal. 6).

\section{METODE}

Penelitian ini menggunakan metode penelitian kualitatif. Desain penelitian yang digunakan dalam penelitian ini adalah penelitian studi kasus. Jumlah subyek yang digunakan dalam penelitian ini berjumlah 2 orang. Teknik yang digunakan dalam pengambilan sampel adalah teknik Non- Probability Sampling dengan teknik purposive sampling. Lokasi penelitian dilakukan ditiga tempat, yaitu disebuah LSM, di kediaman kedua subjek dan sebuah puskesmas. Teknik pengumpulan data yang digunakan oleh peneliti adalah wawancara secara mendalam dan observasi. Analisis data yang digunakan peneliti dalam penelitian ini yaitu metode perbandingan tetap dengan cara membandingkan satu datum dengan datum yang lain, kemudian datum-datum tersebut akan digunakan untuk membandingkan satu kategori dengan kategori yang lain. Untuk mencapai keabsahan data, peneliti menggunakan kriteria kepercayaan dengan teknik triangulasi dengan sumber. Peneliti melakukan perbandingan data hasil pengamatan dengan data hasil wawancara, selain itu peneliti juga menanyakan kembali kepastian jawaban yang telah diberikan.

\section{HASIL}

Dari hasil penelitian, resiliensi kedua subjek hampir sama. Kedua subjek telah berhasil mencapai resiliensi. Untuk mencapai resiliensi, terdapat beberapa level yang dilalui oleh kedua subjek. Level pertama yang dilalui oleh kedua subjek adalah tahap succumbing, pada level ini kedua subjek hampir mempunyai keadaan yang sama. Subyek mengalami ketakutan, diskriminasi dari kesehatan, perasaan bingung, dia istri menyalahkan subjek (subyek I), stigma yg buruk tentang ODHA dan tidak mendapat kepercayaan dari keluarga, suami sering keluar malam (subyek II). Setelah itu, kedua subjek memasuki level survival. Pada level ini kedua subjek mengalami perasaan kecewa, kaget, tidak percaya dan stres yang mengakibatkan kedua subjek mudah tersinggung dan mudah marah, merasa minder bersosialisasi (subyek I), mengalami keguguran dan tidak saling sapa dengan saudaranya (subyek II). Level selanjutnya adalah level pulih kembali atau yang biasa disebut recovery. Dalam level ini kedua subjek telah mengikuti kegiatan-kegiatan yang diadakan oleh kampungnya dan saling menyapa kembali dengan saudaranya setelah 1 tahun (subyek II). Level terahir yang dilalui adalah thryving. Pada level ini kedua subjek pasrah terhadap Allah dan lebih mendekatkan diri kepada-Nya.

Kedua subjek juga mendapatkan semua aspek-aspek yang dapat membentuk resiliensi yang mereka miliki, yaitu aspek I am, I have dan I Can. Pada aspek I am, kedua subyek mempunyai harga diri tinggi. mempunyai problem solving yang baik bertanggungjawab sebagai orang tua, keyakinan akan terkabulnya doa-doanya keinginan untuk menjadi orang yang lebih berguna dan menjadi lebih baik. Pada aspek i have kedua subyek mempunyai dukungan dari teman sesama ODHA dan keluarga, mempunyai seorang penasehat dan anak sebagai penyemangat diri. Aspek yang terahir yaitu i can, pada aspek ini kedua subyek dapat mendengarkan cerita teman dan dapat menyampaikan saran dengan baik serta berdiskusi dengan teman dan keluarga tentang penyakitnya.

Membentuk pribadi yang resilien juga diperlukan beberapa faktor-faktor pembentuk resiliensi kedua subjek yaitu Regulasi emosi dan kontrol impulsif , pada aspek ini kedua subyek merasa kaget, kecewa, 
tidak percaya, bingung dan stres. Sehingga mereka mudah marah dan sering memukul orang lain. Walaupun regulasi mereka bisa dibilang rendah, akan tetapi mereka mempunyai Optimisme, kedua subyek yakin bahwa Allah menyayanginya dan keinginan untuk membuat anaknya sukses. Empati, subyek pertama lebih menunjukan sikap simpati seperti menolong orang yang membutuhkan, sedangkan subyek dua Mengetahui ketika orang lain tidak menyukainya dari sikap, perilaku, tatapan mata dan nada bicara. Kedua subyek juga mempunyai faktor self eficasy, hal tersebut ditunjukan dari perilaku kedua subyek untuk mengatur pola hidup sehatdan mengikuti penyuluhan. Kedua subyek juga dapat mengetahui dari mana mereka dapat terinfeksi HIV, sehingga mereka dapat dikatakan mempunyai kemampuan untuk melakukan kausal analisis. faktor yang terahir yaitu reaching out, kedua subyek diajarkan untuk menjadi pribadi yang mandiri dalam pekerjaan rumah tangga.

\section{DAFTAR PUSTAKA}

Astuti, Apri \& Budiyani, Kondang. 2008. Hubungan Antara Dukungan Sosial yang Diterima dengan Kebermaknaan Hidup pada ODHA (Orang Dengan HIV/AIDS). Fakultas Psikologi. Universitas Mercu Buana Yogyakarta.

Coulson, Ronaye. 2006. Resilience and Self-Talk in University Students. Thesis University of Calgary.

Desmita. 2005. Psikologi Perkembangan. Bandung: PT Remaja Rosdakarya.

Earvolino, M \& Ramirez. 2007. Resilience: a concept analysis. Journal Nursing Forum volume 42, No. 2 April.

E-book building resilience in rural communities.2008. The University of Queensland and University of Southern Queensland.

Hawari, Dadang. 2006. Global Effect HIV/AIDS
Faktor protektif juga diperlukan dalam membentuk resiliensi pada diri individu, kedua subyek mendapatkan dukungan dari keluarga dan sesama ODHA. Anak sebagai alasan mereka dapat bertahan. Mengikuti pelatihan dan penyuluhan. keyakinan bahwa Allah masih menyayanginya dan terkabulnya doa. Lebih mendekatkan diri kepada Allah dengan cara rajin solat baik solat wajib maupun sholat sunnah, membaca Al-quran, mendengarkan ceramah agama, melakukan hal yang berguna bagi orang lain serta melakukan pola hidup sehat untuk menjaga kesehatan.

\section{KESIMPULAN}

Berdasarkan pemaparan hasil dan pembahasan diatas, dapat disimpulkan bahwa kedua individu dapat mengatasi tekanan-tekanan yang terjadi dalam hidupnya dan menjadi pribadi yang lebih baik dari sebelumnya.

Dimensi Psikoreligi. Jakarta: Fakultas Kedokteran Universitas Indonesia.

McCubbin, L. 2001. Chalange to The Definition of Resilience. Paper presented at The Annual Meeting of The American Psychological Association in San Francisco.

Reveich, K\&Shatte, A. 2002.The Resilience actor: seven essential skill for overcoming life's inevitable obstacle. New York: Random House.

Saputra, Bayu Teguh. 2009. Hubungan kepribadian ketangguhan (Hardiness) dan kecerdasan emosional dengan depresi pada orang dengan HIV-AIDS (ODHA). Fakultas Psikologi. Universitas Katolik Soegijapranata Semarang.Skripsi.Tidak diterbitkan.

Schoon, Ingrid. 2006. Risk and Resilience:Adaptation in Changing Times. New York: Cambridge University Press. 